\title{
KARAKTERISTIK BRIKET BERBAHAN CAMPURAN CANGKANG BUAH KARET DAN BATANG SENGGANI DENGAN TEKANAN PENCETAKAN 90 PSI
}

\author{
Elyas Kustiawan $^{1}$, Eka Sari Wijianti ${ }^{2}$, Saparin ${ }^{3}$ \\ 1,2,3 Jurusan Teknik Mesin, Universitas Bangka Belitung \\ Kampus Terpadu Desa Balunijuk Kecamatan Merawang Kabupaten Bangka
}

Email:saparinpdca@gmail.com

\begin{abstract}
Abstrak
Briket atau yang lebih dikenal dengan bahan bakar arang merupakan energi biomassa sebagai salah satu bentuk energi alternatif. Briket mempunyai prospek yang bagus untuk dikembangkan karena pembuatannya yang mudah dan ketersediaan bahan baku yang melimpah di alam. Oleh karena itu penelitian ini berupaya membuat briket dengan kombinasi campuran cangkang buah karet dan batang senggani. Kedua bahan tersebut adalah tanaman yang sangat banyak ditemui di wilayah Bangka Belitung, terutama di area perkebunan dan area hutan. Penelitian dilakukan untuk mengetahui karakteristik briket meliputi kadar air, kadar abu dan nilai kalor sesuai standar mutu SNI 01-6235-2000. Briket dibuat dengan variasi campuran cangkang buah karet : batang senggani yaitu 100\%:0\%, 75\%:25\%, 50\%:50\%, 25\%:75\%, 0\%:100\%. Bahan perekat menggunakan tepung kanji sebanyak 10 gram tiap komposisi campuran. Briket dicetak pada tekanan tetap yaitu 90 psi. Untuk mempercepat proses pengeringan, briket dikeringkan dalam oven dengan temperatur $80^{\circ} \mathrm{C}$ selama $16 \mathrm{jam}$. Hasil penelitian menunjukkan bahwa untuk seluruh variasi komposisi campuran briket, kadar air masih berada di atas 8\% (belum memenuhi standar SNI), kadar abu berada di bawah 8\% (memenuhi standar SNI) dan nilai kalor di atas $5000 \mathrm{Kal} / \mathrm{g}$ (memenuhi standar SNI). Variasi komposisi terbaik adalah komposisi $75 \%$ cangkang buah karet dan $25 \%$ kayu senggani dengan nilai kadar air 10,56\%, kadar abu 4,19\% dan nilai kalor 6123,23 Kal/g. Hal ini disebabkan karena cangkang buah karet sebagai pembawa sifat karakteristik briket yang lebih baik dibandingkan batang senggani.
\end{abstract}

Kata Kunci : Biomassa, Briket, cangkang buah karet, batang senggani, tekanan pencetakan briket.

\begin{abstract}
Briquettes or better known as charcoal fuel is biomass energy as one form of alternative energy. Briquettes have good prospects for development because of their easy manufacturing and availability of raw materials that are abundant in nature. Therefore, this research attempts to make briquettes with a combination of rubber shells and senggani. Both materials are plants that are very much found in the region of Bangka Belitung, especially in plantation areas and forest areas. The research was conducted to know the characteristics of briquettes include moisture content, ash content and heat value according to SNI 01-6235-2000 quality standard. Briquettes are made with a variety of mixed rubber shells: $100 \%$ : 0\%, $75 \%$ : 25\%, 50\%: 50\%, 25\%: 75\%: 0\%: $100 \%$. Adhesives use starches of starch as much as 10 grams per mixture composition. Briquettes are printed at a fixed pressure of 90 psi. To speed up the drying process, the briquette is dried in an oven at $80 \circ \mathrm{C}$ for 16 hours. The results showed that for all variations of briquette mixture composition, water content was still above 8\% (not yet fulfill SNI standard), ash content was below 8\% (meet SNI standard) and heat value above $5000 \mathrm{Kal} / \mathrm{g} \mathrm{SNI}$ ). The best composition variation is $75 \%$ composition of rubber shell and $25 \%$ senggani wood with $10.56 \%$ moisture content, ash content of $4.19 \%$ and calorific value of $6123.23 \mathrm{cal} / \mathrm{g}$. This is due to the shell of the rubber fruit as a carrier of the characteristic characteristics of briquettes better than the senggani.
\end{abstract}

Key Words : Biomass, briqette, rubber shells, stem of senggani, pressure on briquette printing. 


\section{PENDAHULUAN}

Konsumsi energi terus meningkat berbanding lurus dengan pertumbuhan penduduk yang tinggi. Saat ini energi yang digunakan masih bergantung pada bahan bakar fosil yang tidak dapat diperbaharui (nonrenewable) dan tidak berkelanjutan (unsustainable. Perlu upaya nyata untuk mengurangi ketergantungan terhadap energi yang berasal dari bahan bakar tersebut. Cadangan minyak bumi di Indonesia semakin terbatas. Cadangan minyak Indonesia berada pada posisi 28 atau $0,2 \%$ dari cadangan minyak seluruh dunia sebesar 3,7 milyar barel (Energia, 2013). Untuk mengurangi ketergantungan terhadap bahan bakar minyak pemerintah telah menerbitkan peraturan Presiden Republik Indonesia nomor 5 Tahun 2006, tentang kebijakan energi nasional untuk mengembangkan energi alternatif sebagai pengganti bahan bakar minyak. Selain itu, Dalam rangka mengurangi ketergantungan terhadap minyak bumi maka perlu dilakukan penghematan sumber energi dan mencari energi alternatif. Penghematan dapat dilakukan melalui pemanfaatan bahan bakar atau energi alternatif yang bersumber dari energi terbarukan misalnya biomassa. Biomassa adalah material yang berasal dari organisme hidup yang tumbuh-tumbuhan dan produk lainnya seperti sampah kebun, sampah hutan maupun hasil panen yang sudah tidak terpakai. Namun pemanfaatan limbah biomassa itu cenderung kurang efisien, dikarenakan masih memiliki kandungan kadar air yang tinggi, berat jenis rendah, kadar abu yang tinggi dan nilai kalor yang rendah, oleh sebab itu limbah biomassa perlu diproses lagi agar menghasilkan bahan bakar yang lebih efisien.

Metode pembriketan dipilih untuk menghasilkan bahan bakar yang lebih efisien, karena menggunakan alat dan teknologi yang relatif sederhana. Selain itu, nilai kalor yang dihasilkan briket (bahan bakar padat) juga cukup tinggi bila dibandingkan dengan pembakaran biomassa secara langsung. Dalam penelitian Nurhilal dan Setyaningsih 2018 menyatakan bahwa nilai kalor dipengaruhi oleh kadar air dan kadar abu yang terkandung dalam briket. Semakin rendah kadar abu dan kadar air, maka akan meningkatkan nilai kalor briket.

Pada penelitian ini, bahan briket yang dipilih berasal dari sampah kebun yaitu cangkang buah karet dan tanaman senggani. Pohon senggani dapat dilihat pada gambar 1, sedangkan cangkang buah karet dapat dilihat pada gambar 2. Pemilihan tersebut didasarkan karena cangkang buah karet dan tanaman Senggani atau Harendong (Melastoma candidum D.Don) berlimpah, belum dimanfaatkan secara maksimal dan mempunyai potensi untuk dikembangkan. Di Bangka
Belitung khususnya sangat mudah unduk mendapatkan cangkang buah karet dan tanaman senggani.

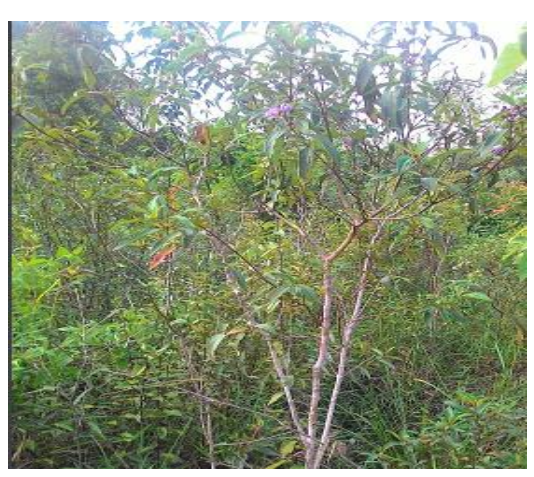

Gambar 1 Pohon Senggani

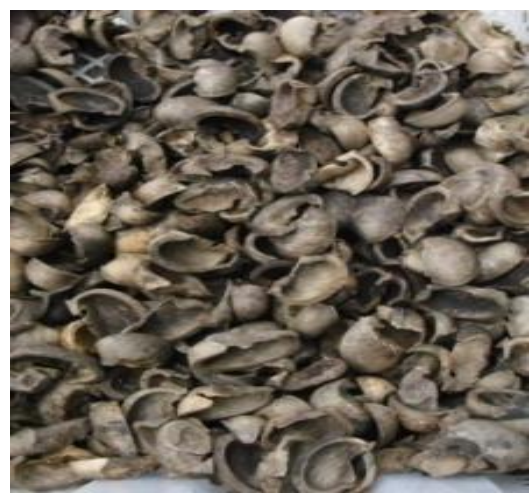

Gambar 2 Cangkang buah karet

Dari bahan-bahan alam tersebut, diharapkan dapat menjadi sumber energi biomass yang berguna bagi kehidupan masyarakat.

\section{METODE PENELITIAN}

Metode yang digunakan pada penelitian ini adalah metode eksprimental, yaitu memvariasikan komposisi campuran bahan pembuat briket. Tekanan pencetakan adalah tetap. Selanjutnya akan dilihat pengaruh tekanan pencetakan terhadap karakteristik briket yang dihasilkan, meliputi nilai kalor, kadar air dan kadar abu. Variasi penelitian dapat dilihat pada tabel berikut:

Tabel 1 Perlakuan variasi komposisi campuran briket

\begin{tabular}{cccc}
\hline No & $\begin{array}{c}\text { Nama } \\
\text { Sampel }\end{array}$ & $\begin{array}{c}\text { Komposisi campuran briket } \\
\text { Cangkang } \\
\text { buah karet } \\
(\%)\end{array}$ & $\begin{array}{c}\text { Batang } \\
\text { senggani (\%) }\end{array}$ \\
\hline $\mathbf{1}$ & $\mathrm{A}$ & 100 & 0 \\
\hline
\end{tabular}

30 Sari Wijianti, Eka, dkk; Karakteristik Briket Berbahan Campuran Cangkang Buah Karet Dan Batang Senggani Dengan Tekanan Pencetakan 90 PSI 


\begin{tabular}{cccc}
\hline No & $\begin{array}{c}\text { Nama } \\
\text { Sampel }\end{array}$ & $\begin{array}{c}\text { Komposisi campuran briket } \\
\text { Cangkang } \\
\text { buah karet } \\
(\boldsymbol{\%})\end{array}$ & $\begin{array}{c}\text { Batang } \\
\text { senggani (\%) }\end{array}$ \\
\hline $\mathbf{2}$ & B & 75 & 25 \\
$\mathbf{3}$ & $\mathrm{C}$ & 50 & 50 \\
$\mathbf{4}$ & $\mathrm{D}$ & 25 & 75 \\
$\mathbf{5}$ & $\mathrm{E}$ & 0 & 100 \\
\hline
\end{tabular}

Variabel pada penelitian ini ada dua yaitu variabel bebas dan variabel pengamatan atau variabel terikat. Variabel bebas adalah variasi campuran bahan. Variabel pengamatan atau variabel terikat antara lain : kadar air, kadar abu dan nilai kalor.

Langkah-langkah penelitian yang dilakukan mengacu pada penelitian Wijianti, dkk (2017) dapat dilihat pada diagram alir (gambar 3) berikut ini.

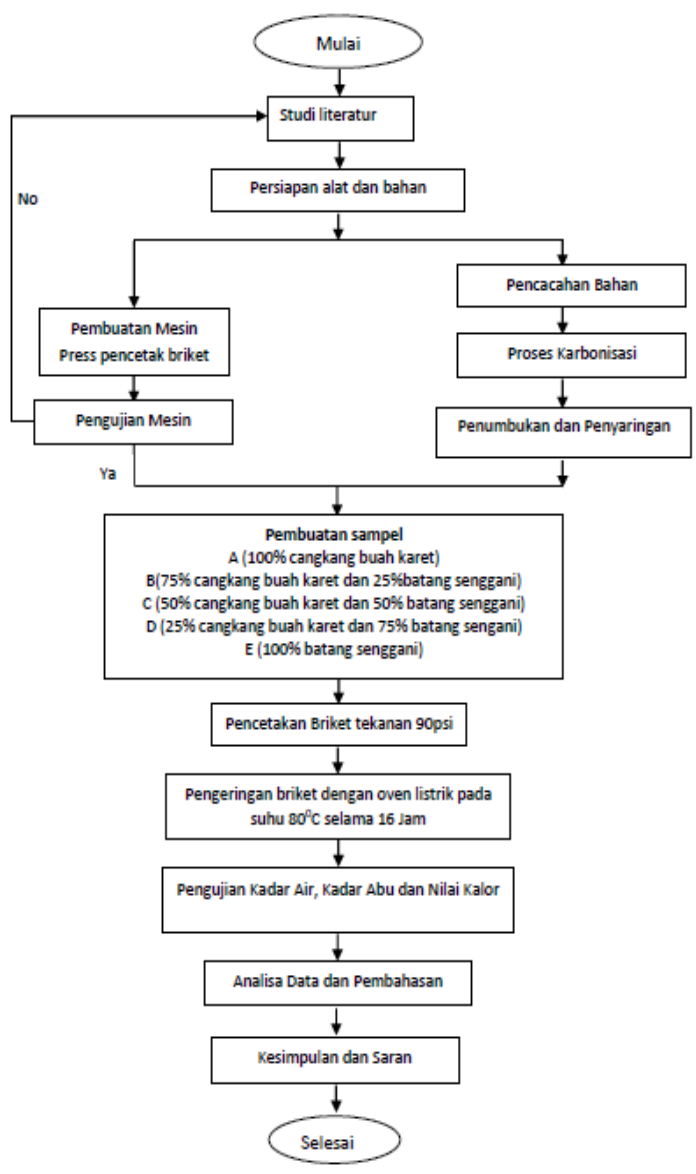

Gambar 3 Diagram alir penelitian

Tahapan-tahapan pada penelitian ini antara lain: pembuatan briket sebagai sampel, tahapan pengujian nilai kalor dan proksimat meliputi kadar air dan kadar abu, dan analisis data pengujian secara statistik. Satu variasi komposisi akan dilakukan tiga kali pengujian, artinya satu komposisi akan dibuat tiga sampel. Hasil yang disajikan adalah hasil ratarata pengujian tiap komposisi.
Peralatan yang digunakan untuk pembuatan briket antara lain:

- Mesin pencetak briket yang dibuat menggunakan hidrolik pneumatik yang sudah dimodifikasi. Cairan oli dibuang untuk memanfaatkan tekanan angin dari kompresor saat mencetak briket.

- Oven digunakan untuk mengeringkan setelah briket dicetak.

- Bomb kalorimeter untuk menguji nilai kalor

Langkah-langkah yang dilakukan dalam pembuatan briket adalah sebagai berikut :

1. Cangkang buah karet dan batang senggani dibersihkan dari kotoran.

2. Batang senggani dipotong menjadi ukuran yang kecil.

3. Cangkang buah karet dan batang senggani dijemur dibawah sinar matahari.

4. Proses karbonisasi : masukkan potongan batang senggani tersebut kedalam wadah pengarangan. Lakukan juga untuk cangkang buah karet secara terpisah.

5. Arang hasil proses pengarangan tersebut kemudian ditumbuk menggunakan lesung batu sehingga menjadi serbuk arang. Selanjutnya serbuk arang tersebut diayak menggunakan ayakan berukuran 18 mess sehingga didapatkan partikel serbuk arang yang seragam.

6. Untuk membuat perekat, 100 gram tepung kanji dicampur dengan $750 \mathrm{ml}$ air, kemudian dimasak sehingga menjadi sebuah perekat.

7. Serbuk arang cangkang buah karet dan serbuk arang senggani dicampur hingga mempunyai masa total 900 gram. variasi campurannya adalah sebagai berikut:

- $25 \%$ serbuk arang cangkang buah karet dan $75 \%$ serbuk arang senggani

- $75 \%$ serbuk arang cangkang buah karet dan $25 \%$ serbuk arang senggani

- $50 \%$ Serbuk arang cangkang buah karet dan $50 \%$ serbuk arang senggani

- $100 \%$ Serbuk arang cangkang buah karet

- $100 \%$ Serbuk arang senggani

Setelah itu perekat dicampurkan sebanyak 10 gram ke masing-masing variasi campuran diatas, aduk sampai merata, kemudian dimasukkan kedalam cetakan dan dipress menggunakan mesin pencetak briket dengan tekanan pencetakan 90 Psi (Wijianti, dkk, 2017).

8. Setelah selesai dicetak, hasil cetakan yaitu sudah berupa briket dikeringkan dengan menggunakan oven pengering/microwave dengan suhu $80^{\circ} \mathrm{C}$ selama 16 jam.

Briket tersebut di uji untuk mengetahui kadar air, kadar abu dan nilai kalor. Pada masingmasing sampel akan dilakukan sebanyak tiga kali pengujian kadar air, kadar abu dan nilai kalor. jadi total sampel briket yang akan di uji sebanyak 15 sampel. 
Standarisasi karakteristik briket dapat dilihat pada tabel berikut:

Tabel 2 Standarisasi kualitas briket arang

\begin{tabular}{ccccc}
\hline $\begin{array}{c}\text { Sifat } \\
\text { Briket } \\
\text { Arang }\end{array}$ & \multicolumn{4}{c}{ Kualifikasi briket arang } \\
\cline { 2 - 5 } & Jepang & Inggris & Amerika & Indonesia \\
\hline $\begin{array}{c}\text { Kadar } \\
\text { Air } \\
(\%)\end{array}$ & $6-8$ & $3-4$ & 6 & Maks8 \\
$\begin{array}{c}\text { Kadar } \\
\text { Abu }\end{array}$ & $3-6$ & $8-10$ & 18 & Maks 8 \\
$\begin{array}{c}\text { Nilai } \\
\text { Kalor }\end{array}$ & $6000-$ & 6500 & 7000 & Min 5000 \\
\hline
\end{tabular}

Sumber: Mangkau dalam Septian (2017)

\section{HASIL DAN PEMBAHASAN}

Briket diuji dengan pengujian nilai kalor dan pengujian proksimat yang meliputi kadar air dan kadar abu.

Tabel 3 Hasil rekapitulasi karakteristik briket

\begin{tabular}{ccccc}
\hline No & $\begin{array}{c}\text { Nama } \\
\text { sampel }\end{array}$ & $\begin{array}{c}\text { Kadar Air } \\
(\%)\end{array}$ & $\begin{array}{c}\text { Kadar } \\
\text { Abu } \\
(\%)\end{array}$ & $\begin{array}{c}\text { Nilai } \\
\text { Kalor } \\
(\mathbf{K a l} / \mathbf{g r})\end{array}$ \\
\hline 1. & A & 8,42 & 3,77 & 6512,13 \\
2. & B & 10,65 & 4,19 & 6123,23 \\
3. & C & 12,11 & 4,78 & 6055,06 \\
\hline 4. & D & 17,12 & 4,85 & 5531,43 \\
5. & E & 16,32 & 5,35 & 5465,95 \\
\hline
\end{tabular}

\section{Kadar Air}

Kadar air terendah yaitu sampel A dengan komposisi $100 \%$ cangkang buah karet yaitu sebesar 8,42\%. Sedangkan untuk variasi komposisi yang kurang baik adalah sampel D dengan komposisi $25 \%$ cangkang buah karet dan $75 \%$ batang senggani yaitu $17,12 \%$.

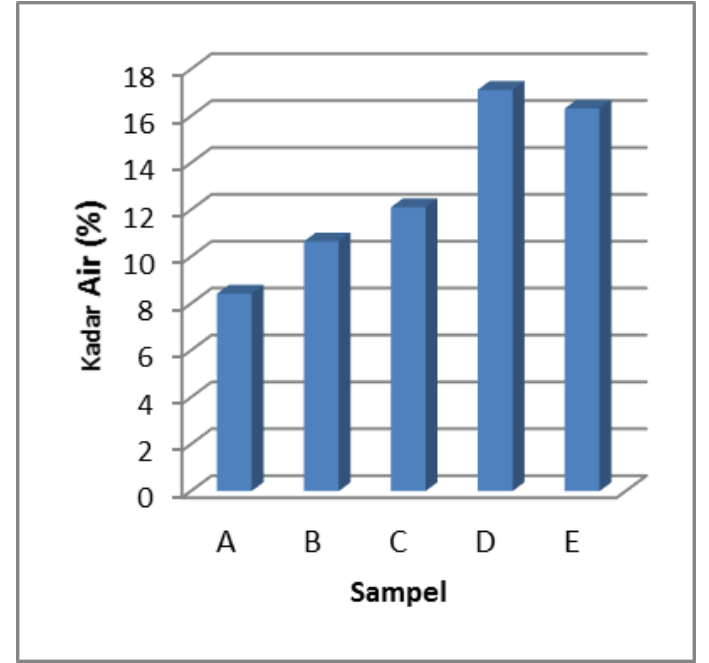

\section{Gambar 4 Nilai kadar air briket}

Dari hasil tersebut dapat dinyatakan bahwa bahan briket dari cangkang buah karet memberikan pengaruh yang baik terhadap karakteristik kadar air briket. Meskipun jika dibandingkan dengan nilai standar, mutu kadar air briket masih berada di atas standar SNI yang mensyaratkan bahwa nilai kadar air briket adalah dibawah $8 \%$.

\section{Kadar Abu}

Pada tabel 2 dapat dilihat pengaruh nyata cangkang buah karet terhadap kadar abu briket. Kadar abu terendah terdapat pada sampel A (100\% cangkang buah karet:0\% senggani, yaitu $3,77 \%$. Sedangkan untuk kadar abu tertinggi terdapat pada sampel E (0\% cangkang buah karet: $100 \%$ senggani) yaitu 5,35\%. Berdasarkan hasil penelitian diperoleh hasil bahwa kadar abu dari bahan cangkang buah karet lebih rendah dibandingkan kadar abu dari bahan senggani.

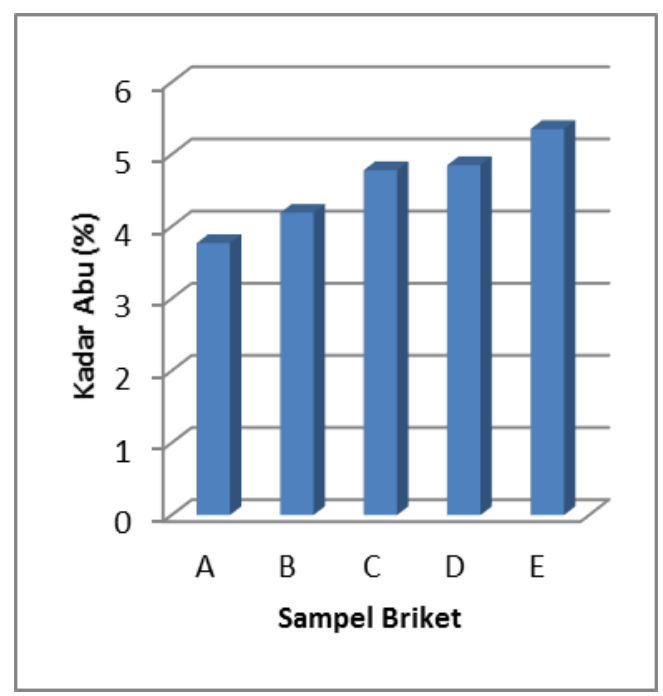

Gambar 5 Nilai kadar abu briket 
Hasil penelitian juga menunjukkan bahwa kadar abu yang dihasilkan memenuhi SNI yaitu dibawah $8 \%$. Kadar abu briket akan berbanding lurus dengan campuran bahan baku sehingga nilai kadar abu pada bahan baku awal tidak berbeda jauh nilainya apabila bahan baku telah dicampur dengan perekat. (Purnomo, 2015).

\section{Nilai Kalor}

Hasil penelitian seperti pada tabel 3 . menunjukkan bahwa nilai kalor terendah diperoleh pada perlakuan E ( $0 \%$ cangkang buah karet: $100 \%$ senggani) yang memiliki nilai kalor 5465,95 Kal/g. sedangkan nilai kalor tertinggi diperoleh pada perlakuan A (100\% cangkang buah karet: 0\% senggani, tekanan 90 Psi) yang memiliki nilai kalor $6512,13 \mathrm{Kal} / \mathrm{g}$.

Dari gambar 6 dapat dilihat bahwa semua hasil uji nilai kalor memenuhi SNI yaitu nilai kalor berada diatas $5000 \mathrm{kal} / \mathrm{g}$. Hasil pengujian juga menunjukkan bahwa nilai kalor juga dipengaruhi oleh kadar air dan kadar abu yang ada dalam briket, semakin rendah kadar air dan kadar abu maka akan meningkatkan nilai kalor briket arang yang dihasilkan.

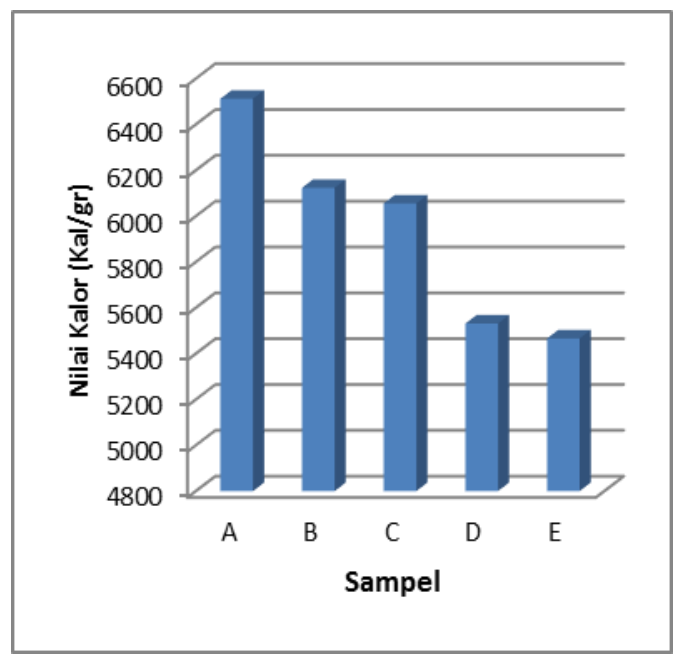

Gambar 6 Nilai kalor briket

Berdasarkan hasil penelitian tersebut dapat dinyatakan bahwa briket dengan bahan campuran cangkang buah karet dan kayu senggani layak digunakan sebagai bahan baku briket karena mempunyai nilai kalor diatas standar SNI.

\section{KESIMPULAN}

Dari penelitian dan analisa data yang telah dilakukan dapat diambil beberapa kesimpulan antara lain :

1. Kadar air briket ini berkisar $8,42-17,12 \%$, nilai ini tidak masuk pada standar SNI 01-6235-2000 yaitu dibawah $8 \%$. Kadar air terendah terdapat pada $100 \%$ cangkang buah karet.

2. Kadar abu berkisar 3,77 - 5,35\%. Kadar abu briket yang dihasilkan memenuhi standar mutu SNI 01-6235-2000 yaitu dibawah $8 \%$. Kadar abu terendah terdapat pada $100 \%$ cangkang buah karet.

3. Nilai kalor berkisar antara 5465,95 - 6512,13 $\mathrm{Kal} /$ gr. Nilai kalor briket yang dihasilkan memenuhi standar mutu SNI 01-6235-2000 yaitu diatas $5000 \mathrm{kal} / \mathrm{g}$. Nilai kalor tertinggi terdapat pada100\% cangkang buah karet.

\section{DAFTAR PUSTAKA}

[1] Eka Sari Wijianti, Yudi Setiawan, Hendra Wisastra . 2017, Briket Arang Berbahan Campuran Ampas Daging Buah Kelapa dan Tongkol Jagung. Machine; Jurnal Teknik Mesin Vol. 3 No. 1, Januari 2017. ISSN : 2502-2040, 30 -35 .

[2] Energia. 2013. Lampu Kuning Cadangan Minyak Indonesia. Jakarta: Pertamina Indonesia, 12 (XLVI).

[3] Erik Taurik Septian, Eka Sari Wijianti, Saparin (2017), Pengaruh Variasi Tekanan Pencetakan Terhadap Karakteristik Briket Berbahan Kayu Senggani Dan Kulit Kayu Bakau, Machine; Jurnal Teknik Mesin Vol. 3 No. 2, Juli 2017. PISSN : 2502-2040 E-ISSN : 2581-0138, Hal 22 29.

[4] Otong Nurhilal, Sri Suryaningsih. (2018), Pengaruh Komposisi Campuran Sabut Dan Tempurung Kelapa Terhadap Nilai Kalor Biobriket Dengan Perekat Molase. Jurnal Ilmu dan Inovasi Fisika Vol. 02, No. 01 (2018) 8-14.

[5] Rahmad Hari Purnomo, Haisen Hower , Inka Rizki Padya. 2015. Pemanfaatan Limbah Biomassa untuk Briket Sebagai Energi Alternatif. Prosiding Seminar Agroindustri dan Lokakarya Nasional FKPT-TPI Program Studi TIP-UTM, 2-3 September 2015.

[6] Nahar. 2012. Pembuatan Briket dari limbah Biomassa. Jurnal Reaksi Jurusan Teknik Kimia Politeknik Negeri Lhokseumawe. Vol. 10 No. 21 : 56-61. 